\title{
Updates of Risk Factors for Anastomotic Leakage after Colorectal Surgery
}

\author{
Eugenia Claudia Zarnescu ${ }^{1,2}$, Narcis Octavian Zarnescu ${ }^{1,2, *}$ and Radu Costea ${ }^{1,2}$ (D) \\ 1 Department of General Surgery, “Carol Davila” University of Medicine and Pharmacy, \\ 050474 Bucharest, Romania; eugenia.zarnescu@umfcd.ro (E.C.Z.); radu.costea@umfcd.ro (R.C.) \\ 2 Second Department of Surgery, University Emergency Hospital Bucharest, 050098 Bucharest, Romania \\ * Correspondence: narcis.zarnescu@umfcd.ro; Tel.: +40-723-592-483
}

Citation: Zarnescu, E.C.; Zarnescu, N.O.; Costea, R. Updates of Risk Factors for Anastomotic Leakage after Colorectal Surgery. Diagnostics 2021, 11, 2382. https://doi.org/10.3390/ diagnostics11122382

Academic Editor: Joaquin Cubiella

Received: 30 September 2021 Accepted: 14 December 2021 Published: 17 December 2021

Publisher's Note: MDPI stays neutral with regard to jurisdictional claims in published maps and institutional affiliations.

Copyright: (c) 2021 by the authors. Licensee MDPI, Basel, Switzerland. This article is an open access article distributed under the terms and conditions of the Creative Commons Attribution (CC BY) license (https:// creativecommons.org/licenses/by/ $4.0 /)$.

\begin{abstract}
Anastomotic leakage is a potentially severe complication occurring after colorectal surgery and can lead to increased morbidity and mortality, permanent stoma formation, and cancer recurrence. Multiple risk factors for anastomotic leak have been identified, and these can allow for better prevention and an earlier diagnosis of this significant complication. There are nonmodifiable factors such as male gender, comorbidities and distance of tumor from anal verge, and modifiable risk factors, including smoking and alcohol consumption, obesity, preoperative radiotherapy and preoperative use of steroids or non-steroidal anti-inflammatory drugs. Perioperative blood transfusion was shown to be an important risk factor for anastomotic failure. Recent studies on the laparoscopic approach in colorectal surgery found no statistical difference in anastomotic leakage rate compared with open surgery. A diverting stoma at the time of primary surgery does not appear to reduce the leak rate but may reduce its clinical consequences and the need for additional surgery if anastomotic leakage does occur. It is still debatable if preoperative bowel preparation should be used, especially for left colon and rectal resections, but studies have shown similar incidence of postoperative leak rate.
\end{abstract}

Keywords: anastomotic leakage; anastomotic fistula; risk factors; colorectal surgery; colorectal cancer

\section{Introduction}

Anastomotic leak (AL) after colorectal surgery is a major complication, increasing postoperative morbidity and mortality. The incidence rate of anastomotic leak after colorectal surgery was reported to be between $2 \%$ and $19 \%$ and the mortality related fistula was reported to be between $0.8 \%$ and $27 \%$ [1-4]. Anastomotic leakage has a significant negative impact on disease-free survival, overall survival and local recurrence $[5,6]$. A meta-analysis including a total of 154,981 patients showed that anastomotic leakage had a negative impact on overall survival [7].

Differences between studies regarding anastomotic leakage rate result from heterogeneity of anastomotic fistula definitions. Different AL rates were reported if the fistula was diagnosed clinically, radiologically, endoscopically or intraoperatively [8-11]. The International Study Group of Rectal Cancer published specific guidelines about the definition of anastomotic leak and a grading system of severity [12]. Later, multiple studies were published that modified the Delphi consensus on the definition and management of anastomotic leakage in colorectal surgery [13-15].

There are multiple studies in the literature that have identified numerous risk factors (Table 1) associated with anastomotic fistula after colorectal surgery, factors that can be divided into local and general factors; pre-, intra- or postoperative factors; and modifiable or non-modifiable factors [16,17]. Identification of risk factors for AL can help surgeons in clinical practice to use a tailored approach for decision making. Multiple studies have identified several risk factors, but unfortunately it is not still possible to perfectly predict the occurrence of fistula for a specific patient. Pre- or intra-operative decisions about whether to perform an anastomosis or a stoma remain difficult. Several leakage scores were developed 
to help surgeons to provide an objective assessment of the risk of AL and in making a decision about surgical management [18-20]. The anastomotic leakage requires further evaluation of its grade of severity that will decide the ultimate management strategies.

Table 1. Risk factors associated with increased risk of postoperative anastomotic leakage (AL) after colorectal surgery.

\begin{tabular}{|c|c|c|c|}
\hline Risk Factors for AL & Pre-Operative & Intra-Operative & Post-Operative \\
\hline Modifiable & $\begin{array}{c}\text { Smoking } \\
\text { Alcohol consumption } \\
\text { Obesity } \\
\text { Malnutrition } \\
\text { Seric albumin and protein level } \\
\text { NSAIDs } \\
\text { Mechanical bowel preparation } \\
\text { Preoperative chemoradiotherapy }\end{array}$ & $\begin{array}{c}\text { Vascularization of digestive segments } \\
\text { Type of suture (manual/mechanical) } \\
\text { Type of approach (open/laparoscopic) } \\
\text { Prophylactic pelvic drainage } \\
\text { Diverting stoma } \\
\text { Blood transfusions }\end{array}$ & $\begin{array}{c}\text { Anemia } \\
\text { Blood transfusions }\end{array}$ \\
\hline Non-modifiable & $\begin{array}{c}\text { Male gender } \\
\text { ASA score }>\text { II } \\
\text { Charlson Comorbidity Index } \\
\text { History of radiotherapy }\end{array}$ & $\begin{array}{c}\text { Distance of tumor from the anal verge } \\
\text { Emergency/elective surgery } \\
\text { Operative time } \\
\text { Surgeon experience }\end{array}$ & \\
\hline
\end{tabular}

\section{Preoperative Risk Factors}

Male gender has been shown to be an independent risk factor for leakage in all types of colorectal anastomosis [21-23]. Jannasch et al. found in their study that leakage was 1.7 times more frequent in men [21]. Anastomosis in the narrower male pelvis results in more difficult resection for men, in both open and laparoscopic colorectal surgery [24]. In a recent study of 429 patients with rectal resections and colorectal anastomosis, the authors found male gender (OR 3.8; 95\% CI 1.9-7.7; $p<0.001$ ) to be an independent variable associated with increased AL rate [25]. The influence of androgen-related differences in the intestinal microcirculation may be involved in anastomoses healing [26]. An experimental study on rats showed a less favorable collagen metabolism in colonic anastomoses of males compared with females during early wound healing [27].

Use of alcohol and smoking is known to have a negative effect on general wound healing [28]. Smoking history and current smokers have a significantly increased risk for leakage. The relationship between the two might be secondary to ischemia caused by smoking-related microvascular disease [29]. Kwak et al. reported habitual smoking to be significantly associated with AL (OR 6.529, $p=0.007)$, and it was suggested that vascular ischemia from nicotine-induced vasoconstriction and microthromboses, together with carbon monoxide-induced cellular hypoxia, inhibits anastomotic circulation in smokers [30]. Alcohol history was also associated with a higher risk of anastomotic leak in several publications [21,29]. Large quantities of alcohol consumption might be a surrogate for poor nutritional status.

The American Society of Anesthesiologists (ASA) score has been shown to be a significant risk factor for postoperative fistula in some studies [31,32]. An ASA grade equal or greater than 3 was reported to be an independent risk factor for anastomotic leakage $[16,21,24,33]$. The presence of comorbid conditions in patients who underwent colorectal surgery was shown to be a risk factor for leakage. Diabetes mellitus [34-36], cardiovascular disease [37], obstructive pulmonary disease [36] and renal failure [38] resulting in a higher Charlson Comorbidity Index (CCI) score [23,32,39] were reported as risk factors. Tian et al. found that patients with a CCI score $\geq 3$ had 1.82 times higher risk of anastomotic leakage compared with patients with a CCI score of zero [39].

Weight and nutrition status are important factors during the evaluation of patients with colorectal anastomosis. Weight loss and malnutrition before surgery have an important role in anastomotic dehiscence, some studies supporting this association [3]. Usually, malnutrition is associated with other factors influencing the healing process [40]. Kwag et al. in their analysis concluded that only patients at nutritional risk have higher complication 
rates after colorectal surgery [41]. There is evidence in the literature to suggest that obesity becomes a risk factor for leaks in very low rectal anastomoses because it may be related to tension at the anastomotic site. A body mass index higher than $30 \mathrm{~kg} / \mathrm{m} 2$ has been shown to be an independent factor for anastomotic leak in some studies $[17,42,43]$. Some authors found that the measurement of visceral fat on CT scan examination is a more sensitive factor than body mass index (BMI) to predict development of anastomotic dehiscence [44,45]. Goulart et al. showed a direct relationship between visceral fat and anastomotic leakage and reoperation [46]. A meta-analysis evaluating visceral fat in patients with laparoscopic colorectal surgery revealed that visceral obesity was associated with longer operative time, less lymph nodes harvested, more conversion to open procedure, higher morbidity, more surgical site infection and more anastomotic leakage [47].

There were authors reporting the preoperative albumin level less than $3.5 \mathrm{~g} / \mathrm{dL}$ as being a significant factor for leakage $[33,48,49]$. In a recent study, the authors found no significant difference in preoperative serum albumin level between the anastomotic leakage group and the non-anastomotic leakage group, but the postoperative serum albumin level was significantly lower in the anastomotic leakage group [50]. In this study, a lower level of serum albumin (less than $3.2 \mathrm{~g} / \mathrm{dL}$ ) on postoperative days 1 and 3, a higher count of leukocytes on postoperative days 1 and 3 , and surgery for rectal cancer were independent risk factors for anastomotic leakage.

Nonsteroidal anti-inflammatory drugs (NSAIDs), which are commonly used analgesic and anti-inflammatory adjuncts, have many physiologic effects and are being used more commonly to treat postoperative pain, but recent small studies have suggested that NSAIDs may impair anastomotic healing [51-53]. In a study by Gorissen et al., patients on NSAIDs had higher anastomotic leakage rates than those not treated with NSAIDs (13.2\% versus $7.6 \% ; p=0.010)$ [54]. However, a multicenter retrospective study found no statistically significant increase in the proportion of patients with anastomotic leak when prescribing nonsteroidal anti-inflammatory drugs for analgesia in the early postoperative period for patients undergoing elective colorectal surgery [55]. This finding is supported by other studies, showing that use of NSAIDs did not increase the risk of anastomotic leakage after anterior resection for rectal cancer [56,57]. Prolonged use of corticosteroids was proposed as a risk factor for anastomotic leakage [58-60]. A prospective study found a significantly increased incidence of anastomotic dehiscence in patients treated with long-term corticosteroids and perioperative corticosteroids for pulmonary comorbidity [61].

Mechanical bowel preparation (MBP) in colorectal surgery has been used for decades, despite increasing evidence challenging its benefits [62,63]. The reason for using MBP is that it reduces fecal bulk, clears the bowel lumen and therefore reduces bacterial colonization, thus decreasing the risk of postoperative complications such as anastomotic dehiscence and wound infection $[64,65]$. On the other hand, MBP has its own complications, such as clinically significant dehydration and electrolyte disturbances in the preoperative period [66,67], and the process is both time-consuming and unpleasant for patients [68]. Opponents of this practice sustain that use of oral and intravenous prophylactic antibiotics are sufficient because the evidence has shown that the gut microbial flora load is not reduced grossly by bowel preparation [69].

In a meta-analysis by Rollins et al. including 21,568 patients undergoing elective colorectal surgery, the authors concluded that the use of MBP versus either absolutely no bowel preparation or a single rectal enema was not associated with a statistically significant difference in the incidence of anastomotic leak, surgical site infection, intra-abdominal collection, mortality, reoperation, or total length of hospital stay [70]. This evidence was supported by other studies [64,71]. Several studies focusing on rectal surgery suggested that mechanical bowel preparation could be used selectively, even though no significant effect was found [72,73]. 
In recent years, authors have shown that a combined preoperative mechanical and oral antibiotics bowel preparation resulted in a significantly decreased risk of overall morbidity, superficial surgical site infection, anastomosis leakage and intra-abdominal infections when compared to no preoperative bowel preparation $[64,74]$. Comparative results assessing the impact of mechanical bowel preparation, with or without oral antibiotics, on postoperative anastomotic leakage are described in Table 2. A retrospective study on 40,446 patients concluded that a combined regimen of oral antibiotics and mechanical bowel preparation offered no superiority when compared with oral antibiotics alone in terms of surgical site infection, anastomotic leak, postoperative ileus and major morbidity after elective colorectal surgery [75]. In conclusion, there is a lack of consensus regarding the use of mechanical bowel preparation due to inconsistent results of the incidence of postoperative complications, including the anastomotic leakage.

Table 2. Comparative results concerning the impact of mechanical bowel preparation on anastomotic leakage.

\begin{tabular}{|c|c|c|c|c|c|c|c|c|}
\hline Authors, Year & $\begin{array}{l}\text { Type of } \\
\text { Study }\end{array}$ & $\begin{array}{c}\text { Location of } \\
\text { Anastomosis }\end{array}$ & $\begin{array}{c}\text { No of } \\
\text { Patients }\end{array}$ & $\begin{array}{l}\text { No Prep. } \\
\text { AL (\%) }\end{array}$ & $\begin{array}{c}\mathrm{MBP}+/ \mathrm{ABX}- \\
\mathrm{AL}, n(\%)\end{array}$ & $\begin{array}{c}\mathrm{MBP}+/ \mathrm{ABX}+ \\
\mathrm{AL}, n(\%)\end{array}$ & $\begin{array}{c}\text { Adjusted OR } \\
(95 \% \text { CI) }\end{array}$ & $p$ \\
\hline $\begin{array}{l}\text { Kiran RP et al., } \\
2015 \text { [64] }\end{array}$ & Retrospective & Colorectal & 8442 & $\begin{array}{l}2296 \\
4.6 \%\end{array}$ & $\begin{array}{l}3822 \\
3.5 \%\end{array}$ & $\begin{array}{c}2424 \\
49(2.1 \%)\end{array}$ & $0.57(0.35-0.94)$ & 0.026 \\
\hline $\begin{array}{l}\text { Ji WB et al., } \\
2017 \text { [72] }\end{array}$ & Retrospective & Rectal & 1369 & $\begin{array}{c}831 \\
9.3 \%\end{array}$ & $\begin{array}{c}538 \\
7.8 \%\end{array}$ & - & & 0.349 \\
\hline $\begin{array}{l}\text { Klinger AL et al., } \\
2019 \text { [74] }\end{array}$ & Retrospective & Colorectal & 27,804 & 5471 & 7617 & 8855 & $0.53(0.43-0.65)$ & $<0.001$ \\
\hline $\begin{array}{c}\text { Garfimkle R } \\
\text { et al., } 2017 \text { [75] }\end{array}$ & Retrospective & Colorectal & 40,446 & $\begin{array}{c}13,219 \\
4.4 \%\end{array}$ & $\begin{array}{c}13,935 \\
3.7 \%\end{array}$ & $\begin{array}{c}11,720 \\
2.3 \%\end{array}$ & $0.53(0.44-0.63)$ & $<0.001$ \\
\hline $\begin{array}{c}\text { Toh JW et al., } \\
2018 \text { [76] }\end{array}$ & Retrospective & Colorectal & 5729 & 1295 & 1713 & 2721 & $\begin{array}{c}\text { Laparoscopic: } \\
0.42 \text { (0.19-0.94) } \\
\text { Open: } \\
0.30(0.12-0.77)\end{array}$ & $\begin{array}{l}0.035 \\
0.012\end{array}$ \\
\hline $\begin{array}{l}\text { Scarborough JE } \\
\text { et al., } 2015 \text { [65] }\end{array}$ & Prospective & Colorectal & 4999 & $\begin{array}{l}1092 \\
5.7 \%\end{array}$ & $\begin{array}{l}2322 \\
4.2 \%\end{array}$ & $\begin{array}{l}1494 \\
2.8 \%\end{array}$ & $0.48(0.32-0.73)$ & 0.001 \\
\hline $\begin{array}{l}\text { Rollins KE et al., } \\
\qquad 2018 \text { [70] }\end{array}$ & $\begin{array}{l}\text { Meta- } \\
\text { analysis }\end{array}$ & Colorectal & 21,568 & $\begin{array}{l}7793 \\
4.8 \%\end{array}$ & 2475 & $\begin{array}{c}11,300 \\
3.7 \%\end{array}$ & $0.90(0.74-1.10)$ & 0.32 \\
\hline
\end{tabular}

$\mathrm{ABX}$-antibiotic treatment; $\mathrm{AL}$-anastomotic leakage; MBP-mechanical bowel preparation.

Preoperative chemoradiotherapy is part of multimodal treatment and is generally recommended for patients with locally advanced rectal cancer followed by TME surgery. It is accepted that these therapeutic modalities can reduce the local recurrence rate $[77,78]$. There are some retrospective studies that have reported an association between preoperative radiotherapy and anastomotic leak [22,79]. A randomized controlled trial on 318 patients with rectal cancer concluded that preoperative radiotherapy increases the risk of anastomotic leakage. The anastomotic leak rate was $20.2 \%$ in patients receiving preoperative radiation and 5-fluorouracil alone and $23.6 \%$ if this therapy was combined with oxaliplatin comparing with $8.5 \%$ in patients with preoperative chemotherapy without radiation $(p=0.007)$ [80]. Prospective trials and cohort studies have shown no statistically significant association between neoadjuvant treatment and anastomotic leakage. A Dutch trial comparing TME plus preoperative radiotherapy versus TME alone reported that there was no significant difference in anastomotic leak rates [81]. In a report using propensity score matching analysis, Chang et al. showed that in patients with rectal cancer, preoperative chemoradiotherapy did not increase the risk of postoperative anastomotic leak after low anterior resection [82]. These results were sustained by other authors in a meta-analysis, showing that neoadjuvant therapy does not appear to increase the incidence of postoperative anastomotic leakage after anterior resection for rectal cancer $[83,84]$. The meta-analysis of $\mathrm{Hu}$ et al. indicated that the incidence of AL was not significantly increased after short-course preoperative RT (OR $=1.19$ [95\% CI: 0.89-1.60; $p=0.25$ ). There was no increase of AL (OR $=1.38 ; 95 \%$ CI: $0.75-2.54 ; p=0.31)$ in patients who had been treated with long-course of preoperative RT [83]. Meta-analysis of Ma et al. showed that 
preoperative RT (PRT) and preoperative chemoradiotherapy (PCRT) significantly increased the incidence of wound problems (PRT: $\mathrm{OR}=1.43,95 \% \mathrm{CI}=1.17-1.74, p<0.01$; PCRT: $\mathrm{OR}=1.52,95 \% \mathrm{CI}=1.08-2.16, p=0.02)$, but not the incidence of anastomotic leakage or bowel obstruction [84]. In this study, the short course and the long course preoperative radiotherapy had similar rates of anastomotic leakage. In addition, the interval to surgery after neoadjuvant therapy and preoperative radiotherapy was not associated with an increased incidence of postoperative leak $[37,83,85]$. Several studies (Table 3) comparing the impact of neoadjuvant therapy on anastomotic leakage are provided for comparison.

Table 3. List of clinical trials comparing the impact of neoadjuvant therapy on anastomotic leakage.

\begin{tabular}{|c|c|c|c|c|c|c|c|}
\hline Authors, Year & Type of Study & $\begin{array}{c}\text { No of } \\
\text { Patients }\end{array}$ & $\begin{array}{c}\text { pR(C)T+Surgery } \\
\text { AL } \%\end{array}$ & $\begin{array}{c}\text { Surgery Alone } \\
\text { AL } \%\end{array}$ & OR, $95 \% \mathrm{CI}$ & $p$ & $\begin{array}{c}\mathrm{pR}(\mathrm{C}) \mathrm{T} \\
\text { Increase } \mathrm{AL}\end{array}$ \\
\hline $\begin{array}{l}\text { Marijnen CA } \\
\text { et al., } 2002 \text { [81] }\end{array}$ & $\begin{array}{l}\text { Prospective } \\
\text { randomized } \\
\text { trial }\end{array}$ & 1414 & $\begin{array}{r}695 \\
11 \%\end{array}$ & $\begin{array}{r}719 \\
12 \%\end{array}$ & - & - & NS \\
\hline $\begin{array}{c}\text { Chang JS et al., } \\
2014 \text { [82] }\end{array}$ & Retrospective & 1437 & $\begin{array}{c}360 \\
7.5 \%\end{array}$ & $\begin{array}{l}1077 \\
5.9 \%\end{array}$ & - & - & NS \\
\hline $\begin{array}{l}\text { Qin Q et al., } \\
2016 \text { [80] }\end{array}$ & $\begin{array}{l}\text { Randomized } \\
\text { controlled trial }\end{array}$ & 318 & $\begin{array}{c}201 \\
13 \%\end{array}$ & $\begin{array}{r}117 \\
4.2 \%\end{array}$ & $\begin{array}{c}\mathrm{OR}=3.50 \\
(95 \% \mathrm{CI} \\
1.20-10.19)\end{array}$ & 0.02 & Yes \\
\hline $\begin{array}{l}\text { Park EJ et al., } \\
2018 \text { [79] }\end{array}$ & Retrospective & 2035 & $\begin{array}{c}427 \\
13.2 \%\end{array}$ & $\begin{array}{l}1608 \\
6.3 \%\end{array}$ & $\begin{array}{c}\mathrm{OR}=1.84 \\
(95 \% \mathrm{CI} \\
1.26-2.69)\end{array}$ & 0.002 & Yes \\
\hline $\begin{array}{l}\text { Qin C et al., } \\
2014 \text { [86] }\end{array}$ & Meta-analysis & 3375 & $\begin{array}{l}1660 \\
8.6 \%\end{array}$ & $\begin{array}{l}1715 \\
8.4 \%\end{array}$ & $\begin{array}{c}\mathrm{OR}=1.02 \\
(95 \% \mathrm{CI} \\
0.80-1.30)\end{array}$ & 0.88 & NS \\
\hline $\begin{array}{l}\text { Hu MH et al., } \\
2017 \text { [83] }\end{array}$ & Meta-analysis & 9675 & $\begin{array}{c}3743 \\
10.6 \%\end{array}$ & $\begin{array}{c}5932 \\
8.54 \%\end{array}$ & $\begin{array}{c}\mathrm{OR}=1.16 \\
(95 \% \mathrm{CI} \\
0.99-1.36)\end{array}$ & 0.07 & NS \\
\hline
\end{tabular}

NS-not significant; $\mathrm{pR}(\mathrm{C}) \mathrm{T}$ - preoperative radio(chemo)therapy.

\section{Intraoperative Risk Factors}

One of the most important risk factors for anastomotic leak is the distance of the suture from the anal verge. Zhang W. et al. showed in a study of 319 patients with middle and low rectal cancer resection that a distance of anastomosis less than $7 \mathrm{~cm}$ from the anal verge is an independent risk factor for leakage [34]. Most studies defined a low rectal anastomosis as an anastomosis $5 \mathrm{~cm}$ or less from the anal verge. Rullier et al. have shown a leak rate 6.5 times higher in anastomoses located less than $5 \mathrm{~cm}$ from the anal verge [87]. In another study of 1392 patients with colorectal cancer, the anastomotic leak rate was $4.7 \%$ in case of extraperitoneal anastomosis compared with $0.2 \%$ in intraperitoneal anastomosis [88]. A meta-analysis on the six studies involving rectal resections only found that a low rectal anastomosis was associated with a high risk of leakage [89]. On the other hand, a retrospective cohort study of 9192 patients with colorectal resections showed no difference in incidence of anastomotic leak of 3\% for patients with pelvic anastomoses and 2.5\% for those with intraabdominal anastomoses [42].

Proper vascularization of digestive segments involved in anastomosis is an important factor that can determine healing on the digestive suture. Recently, measurement of microcirculation has gained substantial interest. Vignali et al. measured transmural colonic blood flow by a laser-Doppler flowmetry technique before bowel manipulation and after vascular ligation and transection [90]. They observed a significant difference $(p<0.001)$ in mean rectal stump flow reduction after colonic division of $16 \%$ in patients who developed anastomotic leak compared with $6.2 \%$ in patients without anastomotic dehiscence. Other authors have measured microvessel density with immunohistochemical analysis of CD31 expression in the proximal segment of anastomosis, but they did 
not find any significant correlation with leakage [91]. An experimental study assessing this issue has shown that total microvascular density should not be measured, but rather functional microvascular density [92]. Recent studies have suggested that near-infrared (NIR) imaging using indocyanine green has a potential benefit in the evaluation of vascular perfusion at the anastomotic site $[25,93,94]$. In a study of 400 patients with colorectal cancer using indocyanine green to assess vascularization of anastomotic margins, the authors showed that 11 patients $(2.8 \%)$ needed to change the transection line by NIR imaging due to fluorescence abnormalities. The rate of AL was $1 \%$. They have concluded that NIR imaging using indocyanine green may contribute to the reduction of anastomotic leak [95].

Surgeon's experience in colorectal surgery has been claimed by some authors to be a risk factor for anastomotic fistula, with a high-volume colorectal surgeons having a smaller incidence of postoperative complications than low-volume ones [96,97]. Other authors found no statistical difference in anastomotic leak rate between consultants, trainee surgeons and independent surgeons [98].

Manual versus mechanical execution of anastomosis is a subject of debate regarding the best results on post-operative anastomotic fistula. Several studies assessing stapled and handsewn colorectal anastomoses found no difference in terms of postoperative leakage rate between the two techniques [99,100]. In a systematic review, Choy et al. compared stapler versus handsewn technique and side-to-side versus end-to-end types of sutures in ileocolic anastomosis [101]. The authors concluded that stapled, functional end-to-end anastomosis is associated with fewer leaks than handsewn ileocolic anastomosis. Puleo et al. analyzed the type of anastomosis technique used in ileocolic anastomosis and found that a handsewn technique was associated with an increased anastomotic leak rate compared with stapled technique [102]. Moreover, they showed that stapled end-to-side configuration was associated with a lower incidence of leak than side-to-side anastomosis. A more recent prospective multicenter international study including 3208 patients evaluated the relationship between leak and anastomosis technique following right-sided colonic resection [103]. The authors found that stapled anastomosis was associated with an increased anastomotic leak rate. Additionally, some authors have reported an increased risk of anastomotic leakage in stapled anastomosis using multiple firing [104,105]. Other authors have shown that there were no significant differences in the rate of anastomotic leakage when comparing either the number or the length of the cartridges used to transect the rectum [106].

Laparoscopic colorectal surgery has recently become popular, and many surgeons currently use this approach in colorectal pathology. Despite the fact that laparoscopic surgery for rectal cancer has technical difficulties such as pelvic approach (especially in men), lack of tactile sense or inadequate cutting angle after transection, the benefits are now widely accepted. Randomized controlled trials confirming equivalent oncological outcome and long-term survival between open and laparoscopic surgery have been published $[107,108]$. Laparoscopy has distinct differences from open surgery, such as the need for multiple stapler firings when transecting the rectum, which is associated with an increased anastomotic leak rate, although this is likely to be reduced with advances in stapler technology [109].

A recent meta-analysis concluded that laparoscopic rectal resection was associated with decreased blood loss, smaller incisions and longer operative times compared with the open approach. No differences were observed for postoperative morbidity and mortality between the two techniques [110]. The COLOR II trial showed statistically significant differences in terms of blood loss, bowel recovery and the length of hospital stay in favor of laparoscopic approach and no difference between open and laparoscopic rectal resection in terms of postoperative anastomotic leakage or mortality [111]. Multiple studies concluded the same things, namely that there were no significant differences between open and laparoscopic rectal resection in terms of anastomotic leakage, postoperative morbidity and mortality $[107,112,113]$. Two recent meta-analysis comparing laparoscopic intersphincteric resection versus open approach for low rectal cancer have shown no significant difference for anastomotic leakage incidence between the two groups [114,115]. 
Modern techniques such as transanal-TME and robotics are receiving worldwide attention recently and may represent an alternative to laparoscopy, especially if they are proven to be oncologically safe, clinically advantageous for the patient and less challenging for the surgeon [116-118]. Robotic colorectal surgery is safe and feasible but has no clear advantages compared with laparoscopic surgery in terms of postoperative outcomes and complications $[119,120]$. Studies showed that the rate of anastomotic leakage was comparable between the two techniques [121,122].

Anastomotic dehiscence remains one of the most significant complications after low anterior resection (LAR) for rectal cancer. Making (constructing) a protective stoma (ileostomy or colostomy) after LAR remains a subject of debate. Even experienced surgeons find it difficult to predict which patients will develop an anastomotic leak, but studies have demonstrated that low anastomosis has a considerably higher risk of dehiscence [123-125]. There are studies and meta-analyses that showed a decreased anastomotic leak rate when surgeons used a defunctioning stoma in LAR by diverting the fecal stream and reducing the intraluminal pressure of the bowel $[16,99,126,127]$. In a multicenter prospective study including rectal cancer patients with anastomoses below $8 \mathrm{~cm}$, leak rate was $5.8 \%$ in the stoma group and $16.3 \%$ in the no stoma group. Leakage rates and reoperation rates for leakage were significantly higher in the group without a stoma. With multivariate analysis, the authors found that male gender and the absence of a stoma were significantly associated with anastomotic leakage [128].

The most commonly used type of stoma is the defunctioning loop ileostomy. Several meta-analyses have compared ileostomies with colostomies and concluded that ileostomy is preferred in terms of reduced stoma-related morbidity $[129,130]$. Some publications have reported that the overall leakage and reoperation rates were similar in patients with or without a protective stoma [131,132]. Moreover, diverting stoma construction and closure is associated with increased morbidity and cost $[133,134]$. The potential disadvantages of a protective stoma include the need for another operation, a longer hospital stay and stoma-related complications, such as prolapse, stenosis, peristomal abscess, parastomal hernia and skin problems. Although it does not reduce the risk of anastomotic fistula, the diverting stoma diminishes its clinical consequences [135-138].

The role of prophylactic pelvic drainage in reducing the postoperative complication rate after rectal surgery remains controversial. New strategies in rectal cancer management including total mesorectal excision (TME) and neoadjuvant chemoradiotherapy have led to a higher rate of sphincter-saving procedures [139]. The utilization of a prophylactic drain reduces extraperitoneal fluid collections, limiting the risk of consequent contamination [140,141]. On the other hand, in the case of anastomotic failure, drainage might help in its early detection and thereby facilitate its proper and early management $[140,141]$. The role of pelvic drainage in reducing the incidence of infraperitoneal anastomotic leakage and pelvic sepsis has been sustained by some authors $[99,106,141,142]$. A recent meta-analysis of randomized controlled trials comparing drainage versus no drainage after rectal surgery found an anastomotic leakage rate of $14.8 \%$ in the drain group and $16.7 \%$ in the no-drain group $(p=0.37)$. The authors concluded that prophylactic use of pelvic drainage after extraperitoneal colorectal anastomosis has no impact on the incidence of anastomotic leak [143]. A meta-analysis by Guerra et al. suggests that pelvic drainage does not confer any significant advantage in the prevention of postoperative complications and may even add to the postoperative morbidity of patients receiving rectal surgery with extraperitoneal anastomoses [144].

According to a study by Denost et al., the overall interval between surgery and the diagnosis of postoperative pelvic sepsis was $7.8 \pm 5.4$ days for drained patients and $6.7 \pm 3.3$ days for undrained patients, and the average delay to reintervention was shorter for patients without pelvic drains [145]. Although this difference had no statistical significance, it suggests a trend to delayed diagnosis of anastomotic leak in patients with pelvic drainage. This prospective randomized trial failed to demonstrate the superiority of the pelvic drainage after low anterior resection for rectal cancer. The authors recommend not 
using pelvic drain after rectal excision for cancer, except in the case of operative bleeding or beyond TME surgery [145].

Emergency surgery in case of peritonitis and/or bowel obstruction places patients at a higher risk of adverse postoperative events. Emergency resection was shown to be an independent risk factor for anastomotic failure in some studies $[16,42]$ and, moreover, an independent risk factor for death after leakage [16]. In a prospective study on $1417 \mathrm{pa-}$ tients with colorectal cancer, Choi et al. found that emergency surgery and a high ASA grade of 3 to 5 are independent factors associated with an increased incidence of leakage. They concluded that a temporary diverting stoma to protect the primary anastomosis or even avoidance of anastomosis could be considered for patients with the two risk factors present [146]. Anastomosis is not necessarily contraindicated in emergency circumstances. There are multiple studies on the feasibility of anastomosis with a defunctioning stoma for peritonitis due to perforated diverticulitis $[147,148]$. However, when performing an emergency resection, the surgeon should evaluate what patients are at a high risk for leakage, and in this situation, use of a temporary defunctioning stoma and avoidance of an anastomosis are sensible and safe options.

Operative time longer than $3 \mathrm{~h}$ has also been described in the literature as being associated with an increased incidence of anastomotic dehiscence [42,48,59,149,150]. Midura et al. categorized anastomotic leaks as minor and major and found that open approach and operative time more than $3 \mathrm{~h}$ were associated with both types of leaks [59].

\section{Postoperative Risk Factors}

Anemia has been described as a risk factor for leaks. Hemoglobin is related to perfusion and oxygenation of the anastomotic margins, an essential factor for anastomotic healing. Currently, this is a subject of assessment, and several authors have shown that a hemoglobin level less than $11 \mathrm{~g} / \mathrm{dL}$ increases risk of leak, as explained by a decreased capacity to transport oxygen to the tissues and subsequent risk of ischemia [151,152].

Operative blood loss and blood transfusions were both independently associated with an increased risk of anastomotic failure [28,153]. Blood loss may induce ischemia at the anastomoses and hence impaired anastomotic healing. Blood transfusions may induce immunological suppression, thereby increasing the risk of infectious conditions around anastomoses [31,154]. In their study, Jannasch et al. found a 1.5-fold risk for anastomotic leak in patients with blood transfusion, without differentiation of the amount of blood units given [21].

\section{Conclusions}

Anastomotic leak after colorectal surgery, a major complication with increased postoperative morbidity and mortality still remains a challenge despite surgical progress and technological advances. The awareness of risk factors should influence treatment and procedure-related decisions. Further research is required to focus on risk factors that currently are insufficiently explored, to reduce the risk and subsequent effects associated with anastomotic leakage.

Author Contributions: Writing—original draft preparation, E.C.Z.; writing—review and editing, N.O.Z. and R.C. All authors have read and agreed to the published version of the manuscript.

Funding: This research received no external funding.

Institutional Review Board Statement: Not applicable.

Informed Consent Statement: Not applicable.

Acknowledgments: We would like to thank Lori Kelly, Anca Bailey and Voichita Ianas for the assistance with English language review.

Conflicts of Interest: The authors declare no conflict of interest. 


\section{References}

1. Akasu, T.; Takawa, M.; Yamamoto, S.; Yamaguchi, T.; Fujita, S.; Moriya, Y. Risk Factors for Anastomotic Leakage Following Intersphincteric Resection for Very Low Rectal Adenocarcinoma. J. Gastrointest. Surg. 2010, 14, 104-111. [CrossRef] [PubMed]

2. Thornton, M.; Joshi, H.; Vimalachandran, C.; Heath, R.; Carter, P.; Gur, U.; Rooney, P. Management and outcome of colorectal anastomotic leaks. Int. J. Color. Dis. 2010, 26, 313-320. [CrossRef]

3. Kang, C.Y.; Halabi, W.J.; Chaudhry, O.O.; Nguyen, V.; Pigazzi, A.; Carmichael, J.C.; Mills, S.; Stamos, M.J. Risk Factors for Anastomotic Leakage After Anterior Resection for Rectal Cancer. JAMA Surg. 2013, 148, 65-71. [CrossRef] [PubMed]

4. A Boccola, M.; Lin, J.; Rozen, W.; Ho, Y.-H. Reducing anastomotic leakage in oncologic colorectal surgery: An evidence-based review. Anticancer Res. 2010, 30, 601-607.

5. Sprenger, T.; Beißbarth, T.; Sauer, R.; Tschmelitsch, J.; Fietkau, R.; Liersch, T.; Hohenberger, W.; Staib, L.; Gaedcke, J.; Raab, H.; et al. Long-term prognostic impact of surgical complications in the German Rectal Cancer Trial CAO/ARO/AIO-94. BJS 2018, 105, 1510-1518. [CrossRef] [PubMed]

6. Wang, S.; Liu, J.; Wang, S.; Zhao, H.; Ge, S.; Wang, W. Adverse Effects of Anastomotic Leakage on Local Recurrence and Survival After Curative Anterior Resection for Rectal Cancer: A Systematic Review and Meta-analysis. World J. Surg. 2016, 41, 277-284. [CrossRef] [PubMed]

7. Lawler, J.; Choynowski, M.; Bailey, K.; Bucholc, M.; Johnston, A.; Sugrue, M. Meta-analysis of the impact of postoperative infective complications on oncological outcomes in colorectal cancer surgery. BJS Open 2020, 4, 737-747. [CrossRef] [PubMed]

8. Mik, M.; Dziki, L.; Berut, M.; Trzcinski, R.; Dziki, A. Neutrophil to Lymphocyte Ratio and C-Reactive Protein as Two Predictive Tools of Anastomotic Leak in Colorectal Cancer Open Surgery. Dig. Surg. 2017, 35, 77-84. [CrossRef] [PubMed]

9. Olsen, B.C.; Sakkestad, S.T.; Pfeffer, F.; Karliczek, A. Rate of Anastomotic Leakage After Rectal Anastomosis Depends on the Definition: Pelvic Abscesses are Significant. Scand. J. Surg. 2019, 108, 241-249. [CrossRef]

10. Tamini, N.; Cassini, D.; Giani, A.; Angrisani, M.; Famularo, S.; Oldani, M.; Montuori, M.; Baldazzi, G.; Gianotti, L. Computed tomography in suspected anastomotic leakage after colorectal surgery: Evaluating mortality rates after false-negative imaging. Eur. J. Trauma Emerg. Surg. 2020, 46, 1049-1053. [CrossRef] [PubMed]

11. Tan, W.J.; Ng, W.Q.; Sultana, R.; De Souza, N.N.; Chew, M.H.; Foo, F.J.; Tang, C.L.; Tan, W.S. Systematic review and meta-analysis of the use of serum procalcitonin levels to predict intra-abdominal infections after colorectal surgery. Int. J. Color. Dis. 2018, 33, 171-180. [CrossRef]

12. Rahbari, N.N.; Weitz, J.; Hohenberger, W.; Heald, R.J.; Moran, B.; Ulrich, A.; Holm, T.; Wong, W.D.; Tiret, E.; Moriya, Y.; et al. Definition and grading of anastomotic leakage following anterior resection of the rectum: A proposal by the International Study Group of Rectal Cancer. Surgery 2010, 147, 339-351. [CrossRef] [PubMed]

13. Daniel, V.T.; Alavi, K.; Davids, J.S.; Sturrock, P.R.; Harnsberger, C.R.; Steele, S.R.; Maykel, J.A. The utility of the delphi method in defining anastomotic leak following colorectal surgery. Am. J. Surg. 2020, 219, 75-79. [CrossRef] [PubMed]

14. Spinelli, A.; Anania, G.; Arezzo, A.; Berti, S.; Bianco, F.; Bianchi, P.P.; De Giuli, M.; De Nardi, P.; De Paolis, P.; Foppa, C.; et al. Italian multi-society modified Delphi consensus on the definition and management of anastomotic leakage in colorectal surgery. Updat. Surg. 2020, 72, 781-792. [CrossRef]

15. Van Helsdingen, C.P.; Jongen, A.C.; De Jonge, W.J.; Bouvy, N.D.; Derikx, J.P. Consensus on the definition of colorectal anastomotic leakage: A modified Delphi study. World J. Gastroenterol. 2020, 26, 3293-3303. [CrossRef]

16. Bakker, I.S.; Grossmann, I.; Henneman, D.; Havenga, K.; Wiggers, T. Risk factors for anastomotic leakage and leak-related mortality after colonic cancer surgery in a nationwide audit. BJS 2014, 101, 424-432. [CrossRef]

17. Frasson, M.; Flor-Lorente, B.; Rodríguez, J.L.R.; Granero-Castro, P.; Hervas, D.; Rico, M.A.A.; Brao, M.J.G.; González, J.M.S.; Granero, E.G. Risk Factors for Anastomotic Leak After Colon Resection for Cancer. Ann. Surg. 2015, 262, 321-330. [CrossRef] [PubMed]

18. Martin, G.; Dupré, A.; Mulliez, A.; Prunel, F.; Slim, K.; Pezet, D. Validation of a score for the early diagnosis of anastomotic leakage following elective colorectal surgery. J. Visc. Surg. 2015, 152, 5-10. [CrossRef] [PubMed]

19. Pasic, F.; Salkic, N.N. Predictive score for anastomotic leakage after elective colorectal cancer surgery: A decision making tool for choice of protective measures. Surg. Endosc. 2013, 27, 3877-3882. [CrossRef] [PubMed]

20. Dekker, J.W.T.; Liefers, G.J.; Otterloo, J.C.D.M.V.; Putter, H.; Tollenaar, R.A. Predicting the Risk of Anastomotic Leakage in Left-sided Colorectal Surgery Using a Colon Leakage Score. J. Surg. Res. 2011, 166, e27-e34. [CrossRef] [PubMed]

21. Jannasch, O.; Klinge, T.; Otto, R.; Chiapponi, C.; Udelnow, A.; Lippert, H.; Bruns, C.J.; Mroczkowski, P. Risk factors, short and long term outcome of anastomotic leaks in rectal cancer. Oncotarget 2015, 6, 36884-36893. [CrossRef] [PubMed]

22. Park, J.S.; Choi, G.-S.; Kim, S.H.; Kim, H.R.; Kim, N.-K.; Lee, K.Y.; Kang, S.B.; Kim, J.Y.; Lee, K.Y.; Kim, B.C.; et al. Multicenter Analysis of Risk Factors for Anastomotic Leakage After Laparoscopic Rectal Cancer Excision. Ann. Surg. 2013, 257, 665-671. [CrossRef] [PubMed]

23. Trencheva, K.; Morrissey, K.P.; Wells, M.; Mancuso, C.A.; Lee, S.W.; Sonoda, T.; Michelassi, F.; Charlson, M.E.; Milsom, J.W. Identifying Important Predictors for Anastomotic Leak After Colon and Rectal Resection. Ann. Surg. 2013, 257, $108-113$. [CrossRef] [PubMed]

24. Arron, M.N.N.; Greijdanus, N.G.; Broek, R.P.G.T.; Dekker, J.W.T.; van Workum, F.; van Goor, H.; Tanis, P.J.; de Wilt, J.H. Trends in risk factors of anastomotic leakage after colorectal cancer surgery (2011-2019): A Dutch population-based study. Color. Dis. 2021. [CrossRef] [PubMed] 
25. Alekseev, M.; Rybakov, E.; Khomyakov, E.; Zarodnyuk, I.; Shelygin, Y. Intraoperative Fluorescence Angiography as an Independent Factor of Anastomotic Leakage and a Nomogram for Predicting Leak for Colorectal Anastomoses. Ann. Coloproctol. 2021. [CrossRef] [PubMed]

26. Ba, Z.F.; Yokoyama, Y.; Toth, B.; Rue, L.W.; Bland, K.I.; Chaudry, I.H. Gender differences in small intestinal endothelial function: Inhibitory role of androgens. Am. J. Physiol. Liver Physiol. 2004, 286, G452-G457. [CrossRef]

27. Kjaer, M.; Kristjánsdóttir, H.; Andersen, L.; Heegaard, A.-M.; Ågren, M.S.; Jorgensen, L.N. The effect of gender on early colonic anastomotic wound healing. Int. J. Color. Dis. 2018, 33, 1269-1276. [CrossRef] [PubMed]

28. Bertelsen, C.A.; Andreasen, A.H.; Jargensen, T.; Harling, H.; on behalf of the Danish Colorectal Cancer Group. Anastomotic leakage after anterior resection for rectal cancer: Risk factors. Color. Dis. 2010, 12, 37-43. [CrossRef] [PubMed]

29. Richards, C.H.; Campbell, V.; Ho, C.; Hayes, J.; Elliott, T.; Thompson-Fawcett, M. Smoking is a major risk factor for anastomotic leak in patients undergoing low anterior resection. Color. Dis. 2011, 14, 628-633. [CrossRef]

30. Kwak, H.D.; Kim, S.-H.; Kang, D.W.; Baek, S.-J.; Kwak, J.M.; Kim, J. Risk Factors and Oncologic Outcomes of Anastomosis Leakage After Laparoscopic Right Colectomy. Surg. Laparosc. Endosc. Percutaneous Tech. 2017, 27, 440-444. [CrossRef]

31. Krarup, P.-M.; Jorgensen, L.N.; Andreasen, A.H.; Harling, H.; on behalf of the Danish Colorectal Cancer Group. A nationwide study on anastomotic leakage after colonic cancer surgery. Color. Dis. 2012, 14, e661-e667. [CrossRef] [PubMed]

32. Sparreboom, C.L.; Van Groningen, J.T.; Lingsma, H.F.; Wouters, M.; Menon, A.G.; Kleinrensink, G.-J.; Jeekel, J.; Lange, J.F. Different Risk Factors for Early and Late Colorectal Anastomotic Leakage in a Nationwide Audit. Dis. Colon Rectum 2018, 61, 1258-1266. [CrossRef] [PubMed]

33. Parthasarathy, M.; Greensmith, M.; Bowers, D.; Groot-Wassink, T. Risk factors for anastomotic leakage after colorectal resection: A retrospective analysis of 17518 patients. Color. Dis. 2017, 19, 288-298. [CrossRef]

34. Zhang, W.; Lou, Z.; Liu, Q.; Meng, R.; Gong, H.; Hao, L.; Liu, P.; Sun, G.; Ma, J. Multicenter analysis of risk factors for anastomotic leakage after middle and low rectal cancer resection without diverting stoma: A retrospective study of 319 consecutive patients. Int. J. Color. Dis. 2017, 32, 1431-1437. [CrossRef] [PubMed]

35. Penna, M.; Hompes, R.; Arnold, S.; Wynn, G.; Austin, R.; Warusavitarne, J.; Moran, B.; Hanna, G.B.; Mortensen, N.J.; Tekkis, P.P. Incidence and Risk Factors for Anastomotic Failure in 1594 Patients Treated by Transanal Total Mesorectal Excision. Ann. Surg. 2019, 269, 700-711. [CrossRef] [PubMed]

36. Rencuzogullari, A.; Benlice, C.; Valente, M.; Abbas, M.A.; Remzi, F.H.; Gorgun, E. Predictors of Anastomotic Leak in Elderly Patients After Colectomy: Nomogram-Based Assessment From the American College of Surgeons National Surgical Quality Program Procedure-Targeted Cohort. Dis. Colon Rectum 2017, 60, 527-536. [CrossRef] [PubMed]

37. Akgun, E.; Caliskan, C.; Bozbiyik, O.; Yoldas, T.; Sezak, M.; Ozkok, S.; Kose, T.; Karabulut, B.; Harman, M.; Ozutemiz, O. Randomized clinical trial of short or long interval between neoadjuvant chemoradiotherapy and surgery for rectal cancer. BJS 2018, 105, 1417-1425. [CrossRef] [PubMed]

38. Alves, Y.P.A.; Panis, Y.; Trancart, D.; Regimbeau, J.-M.; Pocard, M.; Valleur, P. Factors Associated with Clinically Significant Anastomotic Leakage after Large Bowel Resection: Multivariate Analysis of 707 Patients. World J. Surg. 2002, 26, 499-502. [CrossRef] [PubMed]

39. Tian, Y.; Xu, B.; Yu, G.; Li, Y.; Liu, H. Comorbidity and the risk of anastomotic leak in Chinese patients with colorectal cancer undergoing colorectal surgery. Int. J. Color. Dis. 2017, 32, 947-953. [CrossRef] [PubMed]

40. Mäkelä, J.T.; Kiviniemi, H.; Laitinen, S. Risk Factors for Anastomotic Leakage After Left-Sided Colorectal Resection With Rectal Anastomosis. Dis. Colon Rectum 2003, 46, 653-660. [CrossRef] [PubMed]

41. Kwag, S.-J.; Kim, J.-G.; Kang, W.-K.; Lee, J.-K.; Oh, S.-T. The nutritional risk is a independent factor for postoperative morbidity in surgery for colorectal cancer. Ann. Surg. Treat. Res. 2014, 86, 206-211. [CrossRef] [PubMed]

42. Nikolian, V.C.; Kamdar, N.S.; Regenbogen, S.E.; Morris, A.M.; Byrn, J.C.; Suwanabol, P.A.; Campbell, D.A.; Hendren, S. Anastomotic leak after colorectal resection: A population-based study of risk factors and hospital variation. Surgery 2017, 161, 1619-1627. [CrossRef] [PubMed]

43. Akiyoshi, T.; Ueno, M.; Fukunaga, Y.; Nagayama, S.; Fujimoto, Y.; Konishi, T.; Kuroyanagi, H.; Yamaguchi, T. Effect of Body Mass Index on Short-term Outcomes of Patients Undergoing Laparoscopic Resection for Colorectal Cancer. Surg. Laparosc. Endosc. Percutaneous Tech. 2011, 21, 409-414. [CrossRef] [PubMed]

44. Watanabe, J.; Tatsumi, K.; Ota, M.; Suwa, Y.; Suzuki, S.; Watanabe, A.; Ishibe, A.; Watanabe, K.; Akiyama, H.; Ichikawa, Y.; et al. The impact of visceral obesity on surgical outcomes of laparoscopic surgery for colon cancer. Int. J. Color. Dis. 2014, 29, 343-351. [CrossRef] [PubMed]

45. Cakir, H.; Heus, C.; Verduin, W.M.; Lak, A.; Doodeman, H.J.; Bemelman, W.A.; Houdijk, A.P. Visceral obesity, body mass index and risk of complications after colon cancer resection: A retrospective cohort study. Surgery 2015, 157, 909-915. [CrossRef]

46. Goulart, A.; Malheiro, N.; Ríos, H.; Sousa, N.; Leao, P. Influence of Visceral Fat in the Outcomes of Colorectal Cancer. Dig. Surg. 2018, 36, 33-40. [CrossRef] [PubMed]

47. Yang, T.; Wei, M.; He, Y.; Deng, X.; Wang, Z. Impact of visceral obesity on outcomes of laparoscopic colorectal surgery: A metaanalysis. ANZ J. Surg. 2015, 85, 507-513. [CrossRef]

48. Telem, D.A. Risk Factors for Anastomotic Leak Following Colorectal Surgery. Arch. Surg. 2010, 145, 371. [CrossRef]

49. Ionescu, D.; Tibrea, C.; Puia, C. Pre-operative hypoalbuminemia in colorectal cancer patients undergoing elective surgeryA major risk factor for postoperative outcome. Chirurgia 2013, 108, 822-828. [PubMed] 
50. Shimura, T.; Toiyama, Y.; Hiro, J.; Imaoka, H.; Fujikawa, H.; Kobayashi, M.; Ohi, M.; Inoue, Y.; Mohri, Y.; Kusunoki, M. Monitoring perioperative serum albumin can identify anastomotic leakage in colorectal cancer patients with curative intent. Asian J. Surg. 2018, 41, 30-38. [CrossRef] [PubMed]

51. Haddad, N.N.; Bruns, B.R.; Enniss, T.M.; Turay, D.; Sakran, J.V.; Fathalizadeh, A.; Arnold, K.; Murry, J.S.; Carrick, M.M.; Hernandez, M.C.; et al. Perioperative use of nonsteroidal anti-inflammatory drugs and the risk of anastomotic failure in emergency general surgery. J. Trauma Acute Care Surg. 2017, 83, 657-661. [CrossRef]

52. Hakkarainen, T.W.; Steele, S.R.; Bastaworous, A.; Dellinger, E.P.; Farrokhi, E.; Farjah, F.; Florence, M.; Helton, S.; Horton, M.; Pietro, M.; et al. Nonsteroidal Anti-inflammatory Drugs and the Risk for Anastomotic Failure. JAMA Surg. 2015, 150, 223-228. [CrossRef] [PubMed]

53. Bakker, N.; Deelder, J.D.; Richir, M.; Cakir, H.; Doodeman, H.J.; Schreurs, W.H.; Houdijk, A.P. Risk of anastomotic leakage with nonsteroidal anti-inflammatory drugs within an enhanced recovery program. J. Gastrointest. Surg. 2015, 20, 776-782. [CrossRef]

54. Gorissen, K.J.; Benning, D.; Berghmans, T.; Snoeijs, M.; Sosef, M.N.; Hulsewe, K.W.E.; Luyer, M.D.P. Risk of anastomotic leakage with non-steroidal anti-inflammatory drugs in colorectal surgery. BJS 2012, 99, 721-727. [CrossRef] [PubMed]

55. Paulasir, S.; Kaoutzanis, C.; Welch, K.B.; Vandewarker, J.F.; Krapohl, G.; Lampman, R.M.; Franz, M.G.; Cleary, R.K. Nonsteroidal Anti-inflammatory Drugs. Dis. Colon Rectum 2015, 58, 870-877. [CrossRef] [PubMed]

56. Hultberg, D.K.; Angenete, E.; Lydrup, M.-L.; Rutegård, J.; Matthiessen, P. Nonsteroidal anti-inflammatory drugs and the risk of anastomotic leakage after anterior resection for rectal cancer. Eur. J. Surg. Oncol. (EJSO) 2017, 43, 1908-1914. [CrossRef] [PubMed]

57. Westermark, S.; Hultberg, D.K.; Matthiessen, P. Non-Steroidal Anti-Inflammatory Drug Use and Risk of Anastomotic Leakage after Anterior Resection: A Protocol-Based Study. Dig. Surg. 2016, 33, 129-135. [CrossRef]

58. Eriksen, T.F.; Lassen, C.B.; Gögenur, I. Treatment with corticosteroids and the risk of anastomotic leakage following lower gastrointestinal surgery: A literature survey. Color. Dis. 2014, 16, O154-O160. [CrossRef] [PubMed]

59. Midura, E.F.; Hanseman, D.; Davis, B.R.; Atkinson, S.J.; Abbott, D.E.; Shah, S.A.; Paquette, I.M. Risk Factors and Consequences of Anastomotic Leak After Colectomy. Dis. Colon Rectum 2015, 58, 333-338. [CrossRef] [PubMed]

60. Konishi, T.; Watanabe, T.; Kishimoto, J.; Nagawa, H. Risk Factors for Anastomotic Leakage after Surgery for Colorectal Cancer: Results of Prospective Surveillance. J. Am. Coll. Surg. 2006, 202, 439-444. [CrossRef] [PubMed]

61. Slieker, J.C.; Komen, N.; Mannaerts, G.H.; Karsten, T.M.; Willemsen, P.; Murawska, M.; Jeekel, J.; Lange, J.F. Long-term and Perioperative Corticosteroids in Anastomotic Leakage. Arch. Surg. 2012, 147, 447-452. [CrossRef] [PubMed]

62. Battersby, C.; Battersby, N.; Slade, D.; Soop, M.; Walsh, C. Preoperative mechanical and oral antibiotic bowel preparation to reduce infectious complications of colorectal surgery-The need for updated guidelines. J. Hosp. Infect. 2019, 101, 295-299. [CrossRef] [PubMed]

63. Liu, Z.; Yang, M.; Zhao, Z.-X.; Guan, X.; Jiang, Z.; Chen, H.-P.; Wang, S.; Quan, J.-C.; Yang, R.-K.; Wang, X.-S. Current practice patterns of preoperative bowel preparation in colorectal surgery: A nation-wide survey by the Chinese Society of Colorectal Cancer. World J. Surg. Oncol. 2018, 16, 134. [CrossRef] [PubMed]

64. Kiran, R.P.; Murray, A.C.A.; Chiuzan, C.; Estrada, D.; Forde, K. Combined Preoperative Mechanical Bowel Preparation With Oral Antibiotics Significantly Reduces Surgical Site Infection, Anastomotic Leak, and Ileus After Colorectal Surgery. Ann. Surg. 2015, 262, 416-425. [CrossRef] [PubMed]

65. Scarborough, J.E.; Mantyh, C.R.; Sun, Z.; Migaly, J. Combined Mechanical and Oral Antibiotic Bowel Preparation Reduces Incisional Surgical Site Infection and Anastomotic Leak Rates After Elective Colorectal Resection. Ann. Surg. 2015, 262, 331-337. [CrossRef] [PubMed]

66. Sanders, G.; Mercer, S.; Saeb-Parsey, K.; A Akhavani, M.; Hosie, K.B.; Lambert, A.W. Randomized clinical trial of intravenous fluid replacement during bowel preparation for surgery. BJS 2002, 88, 1363-1365. [CrossRef] [PubMed]

67. Shapira, Z.; Feldman, L.; Lavy, R.; Weissgarten, J.; Haitov, Z.; Halevy, A. Bowel preparation: Comparing metabolic and electrolyte changes when using sodium phosphate/polyethylene glycol. Int. J. Surg. 2010, 8, 356-358. [CrossRef] [PubMed]

68. Jung, B.; Lannerstad, O.; Påhlman, L.; Arodell, M.; Unosson, M.; Nilsson, E. Preoperative mechanical preparation of the colon: The patient's experience. BMC Surg. 2007, 7, 5. [CrossRef] [PubMed]

69. Jung, B.; Matthiessen, P.; Smedh, K.; Nilsson, E.; Ransjö, U.; Påhlman, L. Mechanical bowel preparation does not affect the intramucosal bacterial colony count. Int. J. Color. Dis. 2009, 25, 439-442. [CrossRef] [PubMed]

70. Rollins, K.; Javanmard-Emamghissi, H.; Lobo, D.N. Impact of mechanical bowel preparation in elective colorectal surgery: A meta-analysis. World J. Gastroenterol. 2018, 24, 519-536. [CrossRef]

71. Mai-Phan, A.T.; Nguyen, H.; Nguyen, T.T.; A Nguyen, D.; Thai, T.T. Randomized controlled trial of mechanical bowel preparation for laparoscopy-assisted colectomy. Asian J. Endosc. Surg. 2019, 12, 408-411. [CrossRef]

72. Ji, W.B.; Hahn, K.Y.; Kwak, J.M.; Kang, D.W.; Baek, S.J.; Kim, J.; Kim, S.H. Mechanical Bowel Preparation Does Not Affect Clinical Severity of Anastomotic Leakage in Rectal Cancer Surgery. World J. Surg. 2016, 41, 1366-1374. [CrossRef] [PubMed]

73. Pittet, O.; Nocito, A.; Balke, H.; Duvoisin, C.; Clavien, P.A.; Demartines, N.; Hahnloser, D. Rectal enema is an alternative to full mechanical bowel preparation for primary rectal cancer surgery. Color. Dis. 2015, 17, 1007-1010. [CrossRef] [PubMed]

74. Klinger, A.L.; Green, H.; Monlezun, D.J.; Beck, D.; Kann, B.; Vargas, H.D.; Whitlow, C.; Margolin, D. The Role of Bowel Preparation in Colorectal Surgery. Ann. Surg. 2019, 269, 671-677. [CrossRef] [PubMed] 
75. Garfinkle, R.; Abou-Khalil, J.; Morin, N.; Ghitulescu, G.; Vasilevsky, C.-A.; Gordon, P.; Demian, M.; Boutros, M. Is There a Role for Oral Antibiotic Preparation Alone Before Colorectal Surgery? ACS-NSQIP Analysis by Coarsened Exact Matching. Dis. Colon Rectum 2017, 60, 729-737. [CrossRef] [PubMed]

76. Toh, J.W.T.; Phan, K.; Ctercteko, G.; Pathma-Nathan, N.; El-Khoury, T.; Richardson, A.; Morgan, G.; Tang, R.; Zeng, M.; Donovan, S.; et al. The role of mechanical bowel preparation and oral antibiotics for left-sided laparoscopic and open elective restorative colorectal surgery with and without faecal diversion. Int. J. Color. Dis. 2018, 33, 1781-1791. [CrossRef] [PubMed]

77. Rahbari, N.N.; Elbers, H.; Askoxylakis, V.; Motschall, E.; Bork, U.; Büchler, M.W.; Weitz, J.; Koch, M. Neoadjuvant Radiotherapy for Rectal Cancer: Meta-analysis of Randomized Controlled Trials. Ann. Surg. Oncol. 2013, 20, 4169-4182. [CrossRef] [PubMed]

78. Martin, S.T.; Heneghan, H.; Winter, D.C. Systematic review and meta-analysis of outcomes following pathological complete response to neoadjuvant chemoradiotherapy for rectal cancer. BJS 2012, 99, 918-928. [CrossRef]

79. Park, E.J.; Kang, J.; Hur, H.; Min, B.S.; Baik, S.H.; Lee, K.Y.; Kim, N.K. Different clinical features according to the anastomotic leakage subtypes after rectal cancer surgeries: Contained vs. free leakages. PLoS ONE 2018, 13, e0208572. [CrossRef] [PubMed]

80. Qin, Q.; Ma, T.; Deng, Y.; Zheng, J.; Zhou, Z.; Wang, H.; Wang, L.; Wang, J. Impact of Preoperative Radiotherapy on Anastomotic Leakage and Stenosis After Rectal Cancer Resection: Post Hoc Analysis of a Randomized Controlled Trial. Dis. Colon Rectum 2016, 59, 934-942. [CrossRef]

81. Marijnen, C.A.; Kapiteijn, E.; Van De Velde, C.J.; Martijn, H.; Steup, W.H.; Wiggers, T.; Kranenbarg, E.K.; Leer, J.W.; the Cooperative Investigators of the Dutch Colorectal Cancer Group. Acute Side Effects and Complications After Short-Term Preoperative Radiotherapy Combined With Total Mesorectal Excision in Primary Rectal Cancer: Report of a Multicenter Randomized Trial. J. Clin. Oncol. 2002, 20, 817-825. [CrossRef] [PubMed]

82. Chang, J.S.; Keum, K.C.; Kim, N.-K.; Baik, S.H.; Min, B.S.; Huh, H.; Lee, C.G.; Koom, W.S. Preoperative Chemoradiotherapy Effects on Anastomotic Leakage After Rectal Cancer Resection. Ann. Surg. 2014, 259, 516-521. [CrossRef]

83. Hu, M.; Huang, R.-K.; Zhao, R.-S.; Yang, K.-L.; Wang, H. Does neoadjuvant therapy increase the incidence of anastomotic leakage after anterior resection for mid and low rectal cancer? A systematic review and meta-analysis. Color. Dis. 2017, 19, 16-26. [CrossRef]

84. Ma, B.; Gao, P.; Wang, H.; Xu, Q.; Song, Y.; Huang, X.; Sun, J.; Zhao, J.; Luo, J.; Sun, Y.; et al. What has preoperative radio(chemo)therapy brought to localized rectal cancer patients in terms of perioperative and long-term outcomes over the past decades? A systematic review and meta-analysis based on 41,121 patients. Int. J. Cancer 2017, 141, 1052-1065. [CrossRef] [PubMed]

85. Du, D.; Su, Z.; Wang, D.; Liu, W.; Wei, Z. Optimal Interval to Surgery After Neoadjuvant Chemoradiotherapy in Rectal Cancer: A Systematic Review and Meta-analysis. Clin. Color. Cancer 2018, 17, 13-24. [CrossRef] [PubMed]

86. Qin, C.; Ren, X.; Xu, K.; Chen, Z.; He, Y.; Song, X. Does Preoperative Radio(chemo)therapy Increase Anastomotic Leakage in Rectal Cancer Surgery? A Meta-Analysis of Randomized Controlled Trials. Gastroenterol. Res. Pr. 2014, 2014, 1-7. [CrossRef]

87. Rullier, E.; Laurent, C.; Garrelon, J.L.; Michel, P.; Saric, J.; Parneix, M. Risk factors for anastomotic leakage after resection of rectal cancer. BJS 2003, 85, 355-358. [CrossRef]

88. Killingback, M.; Barron, P.; Dent, O. Elective resection and anastomosis for colorectal cancer: A prospective audit of mortality and morbidity 1976-1998. ANZ J. Surg. 2002, 72, 689-698. [CrossRef] [PubMed]

89. Pommergaard, H.-C.; Gessler, B.; Burcharth, J.; Angenete, E.; Haglind, E.; Rosenberg, J. Preoperative risk factors for anastomotic leakage after resection for colorectal cancer: A systematic review and meta-analysis. Color. Dis. 2014, 16, 662-671. [CrossRef] [PubMed]

90. Vignali, A.; Gianotti, L.; Braga, M.; Radaelli, G.; Malvezzi, L.; Di Carlo, V. Altered microperfusion at the rectal stump is predictive for rectal anastomotic leak. Dis. Colon Rectum 2000, 43, 76-82. [CrossRef] [PubMed]

91. Schouten, S.B.; De Bruin, A.F.J.; Gosselink, M.P.; Nigg, A.L.; Van Iterson, M.; Biermann, K.; Kliffen, M.; Van Der Harst, E. Is microvessel density correlated with anastomotic leakage after low anterior resection? Hepatogastroenterology 2014, 61, 90-93. [PubMed]

92. Diller, R.; Stratmann, U.; Helmschmied, T.; Bäumer, G.; Bahde, R.; Minin, E.; Spiegel, H.-U. Microcirculatory Dysfunction in Endotoxemic Bowel Anastomosis: The Pathogenetic Contribution of Microcirculatory Dysfunction to Endotoxemia-Induced Healing Impairment. J. Surg. Res. 2008, 150, 3-10. [CrossRef]

93. Wada, T.; Kawada, K.; Hoshino, N.; Inamoto, S.; Yoshitomi, M.; Hida, K.; Sakai, Y. The effects of intraoperative ICG fluorescence angiography in laparoscopic low anterior resection: A propensity score-matched study. Int. J. Clin. Oncol. 2019, 24, 394-402. [CrossRef] [PubMed]

94. Watanabe, J.; Ishibe, A.; Suwa, Y.; Suwa, H.; Ota, M.; Kunisaki, C.; Endo, I. Indocyanine green fluorescence imaging to reduce the risk of anastomotic leakage in laparoscopic low anterior resection for rectal cancer: A propensity score-matched cohort study. Surg. Endosc. 2019, 34, 202-208. [CrossRef] [PubMed]

95. Ohya, H.; Watanabe, J.; Suwa, H.; Suwa, Y.; Ishibe, A.; Masui, H.; Nagahori, K.; Kunisaki, C.; Endo, I. Incidence and risk factors for fluorescence abnormalities on near-infrared imaging using indocyanine green in stapled functional end-to-end anastomosis in laparoscopic colectomy. Int. J. Color. Dis. 2020, 35, 2011-2018. [CrossRef]

96. Granero, E.G.; Navarro, F.; Santacruz, C.C.; Frasson, M.; García-Granero, A.; Marinello, F.; Flor-Lorente, B.; Espí, A. Individual surgeon is an independent risk factor for leak after double-stapled colorectal anastomosis: An institutional analysis of 800 patients. Surgery 2017, 162, 1006-1016. [CrossRef] [PubMed]

97. Biondo, S.; Kreisler, E.; Millan, M.; Fraccalvieri, D.; Golda, T.; Frago, R.; Miguel, B. Impact of Surgical Specialization on Emergency Colorectal Surgery Outcomes. Arch. Surg. 2010, 145, 79-86. [CrossRef] [PubMed] 
98. Kelly, M.; Bhangu, A.; Singh, P.; Fitzgerald, J.E.F.; Tekkis, P.P. Systematic review and meta-analysis of trainee- versus expert surgeon-performed colorectal resection. BJS 2014, 101, 750-759. [CrossRef]

99. Peeters, K.C.M.J.; Tollenaar, R.A.E.M.; Marijnen, C.; Kranenbarg, E.K.; Steup, W.H.; Wiggers, T.; Rutten, H.J.; van de Velde, C.J.H. Risk factors for anastomotic failure after total mesorectal excision of rectal cancer. BJS 2005, 92, 211-216. [CrossRef] [PubMed]

100. Neutzling, C.B.; Lustosa, S.A.S.; Proenca, I.M.; Da Silva, E.M.K.; Matos, D. Stapled versus handsewn methods for colorectal anastomosis surgery. Cochrane Database Syst. Rev. 2012, 2, CD003144. [CrossRef]

101. Choy, P.Y.G.; Bissett, I.P.; Docherty, J.G.; Parry, B.R.; Merrie, A.; Fitzgerald, A. Stapled versus handsewn methods for ileocolic anastomoses. Cochrane Database Syst. Rev. 2011, 9, CD004320. [CrossRef] [PubMed]

102. Puleo, S.; Sofia, M.; Trovato, M.A.; Pesce, A.; Portale, T.R.; Russello, D.; La Greca, G. Ileocolonic anastomosis: Preferred techniques in 999 patients. A multicentric study. Surg. Today 2012, 43, 1145-1149. [CrossRef] [PubMed]

103. The 2015 European Society of Coloproctology Collaborating Group; Battersby, N.; Bhangu, A.; Chaudhri, S.; El-Hussuna, A.; Frasson, M.; Nepogodiev, D.; Singh, B.; Vennix, S.; Zmora, O.; et al. Relationship between method of anastomosis and anastomotic failure after right hemicolectomy and ileo-caecal resection: An international snapshot audit. Color. Dis. 2017, 19. [CrossRef]

104. Kayano, H.; Okuda, J.; Tanaka, K.; Kondo, K.; Tanigawa, N. Evaluation of the learning curve in laparoscopic low anterior resection for rectal cancer. Surg. Endosc. 2011, 25, 2972-2979. [CrossRef] [PubMed]

105. Balciscueta, Z.; Uribe, N.; Caubet, L.; López, M.; Torrijo, I.; Tabet, J.; Martín, M.C. Impact of the number of stapler firings on anastomotic leakage in laparoscopic rectal surgery: A systematic review and meta-analysis. Tech. Coloproctol. 2020, 24, 919-925. [CrossRef] [PubMed]

106. Akiyoshi, T.; Ueno, M.; Fukunaga, Y.; Nagayama, S.; Fujimoto, Y.; Konishi, T.; Kuroyanagi, H.; Yamaguchi, T. Incidence of and risk factors for anastomotic leakage after laparoscopic anterior resection with intracorporeal rectal transection and double-stapling technique anastomosis for rectal cancer. Am. J. Surg. 2011, 202, 259-264. [CrossRef] [PubMed]

107. Fleshman, J.W.; E Branda, M.; Sargent, D.J.; Boller, A.M.; George, V.; A Abbas, M.; Peters, W.R.; Maun, D.; Chang, G.; Herline, A.J.; et al. Effect of Laparoscopic-Assisted Resection vs Open Resection of Stage II or III Rectal Cancer on Pathologic Outcomes. JAMA 2015, 314, 1346-1355. [CrossRef] [PubMed]

108. Stevenson, A.R.L.; Solomon, M.; Lumley, J.W.; Hewett, P.; Clouston, A.; Gebski, V.; Davies, L.; Wilson, C.; Hague, W.; Simes, J. Effect of Laparoscopic-Assisted Resection vs Open Resection on Pathological Outcomes in Rectal Cancer: The ALaCaRT Randomized Clinical Trial. JAMA 2015, 314, 1356-1363. [CrossRef] [PubMed]

109. Kim, C.W.; Baek, S.J.; Hur, H.; Min, B.S.; Baik, S.H.; Kim, N.-K. Anastomotic Leakage After Low Anterior Resection for Rectal Cancer Is Different Between Minimally Invasive Surgery and Open Surgery. Ann. Surg. 2016, 263, 130-137. [CrossRef] [PubMed]

110. Martínez-Pérez, A.; Carra, M.C.; Brunetti, F.; De'Angelis, N. Short-term clinical outcomes of laparoscopic vs open rectal excision for rectal cancer: A systematic review and meta-analysis. World J. Gastroenterol. 2017, 23, 7906-7916. [CrossRef] [PubMed]

111. Van der Pas, M.H.; Haglind, E.; A Cuesta, M.; Fürst, A.; Lacy, A.M.; Hop, W.C.; Bonjer, H.J. Laparoscopic versus open surgery for rectal cancer (COLOR II): Short-term outcomes of a randomised, phase 3 trial. Lancet Oncol. 2013, 14, 210-218. [CrossRef]

112. Ng, S.S.M.; Lee, J.F.Y.; Yiu, R.Y.C.; Li, J.C.M.; Hon, S.S.F.; Mak, T.W.C.; Ngo, D.K.Y.; Leung, W.W.; Leung, K.L. Laparoscopicassisted versus open total mesorectal excision with anal sphincter preservation for mid and low rectal cancer: A prospective, randomized trial. Surg. Endosc. 2013, 28, 297-306. [CrossRef]

113. Kang, S.-B.; Park, J.W.; Jeong, S.-Y.; Nam, B.H.; Choi, H.S.; Kim, D.-W.; Lim, S.-B.; Lee, T.-G.; Kim, D.Y.; Kim, J.-S.; et al. Open versus laparoscopic surgery for mid or low rectal cancer after neoadjuvant chemoradiotherapy (COREAN trial): Short-term outcomes of an open-label randomised controlled trial. Lancet Oncol. 2010, 11, 637-645. [CrossRef]

114. Zhang, X.; Wu, Q.; Hu, T.; Gu, C.; Xubing, Z.; Wang, Z. Laparoscopic Versus Conventional Open Surgery in Intersphincteric Resection for Low Rectal Cancer: A Systematic Review and Meta-Analysis. J. Laparoendosc. Adv. Surg. Tech. 2018, 28, 189-200. [CrossRef] [PubMed]

115. Chen, H.; Ma, B.; Gao, P.; Wang, H.; Song, Y.; Tong, L.; Li, P.; Wang, Z. Laparoscopic intersphincteric resection versus an open approach for low rectal cancer: A meta-analysis. World J. Surg. Oncol. 2017, 15, 229. [CrossRef] [PubMed]

116. Penna, M.; Hompes, R.; Arnold, S.; Wynn, G.; Austin, R.; Warusavitarne, J.; Moran, B.; Hanna, G.B.; Mortensen, N.J.; Tekkis, P.P. Transanal Total Mesorectal Excision. Ann. Surg. 2017, 266, 111-117. [CrossRef] [PubMed]

117. Burke, J.P.; Martin-Perez, B.; Khan, A.; Nassif, G.; Debeche-Adams, T.; Larach, S.W.; Albert, M.R.; Atallah, S. Transanal total mesorectal excision for rectal cancer: Early outcomes in 50 consecutive patients. Color. Dis. 2016, 18, 570-577. [CrossRef] [PubMed]

118. De'Angelis, N.; Portigliotti, L.; Brunetti, F. Robot-assisted rectal cancer surgery deserves a fair trial. Color. Dis. 2015, 17, 824-825. [CrossRef] [PubMed]

119. Aly, E.H. Robotic colorectal surgery: Summary of the current evidence. Int. J. Color. Dis. 2013, 29, 1-8. [CrossRef]

120. Petrucciani, N.; Sirimarco, D.; Nigri, G.; Magistri, P.; La Torre, M.; D’Angelo, F.; Ramacciato, G.; Aurello, P. Robotic right colectomy: A worthwhile procedure? Results of a meta-analysis of trials comparing robotic versus laparoscopic right colectomy. J. Minimal Access Surg. 2015, 11, 22-28. [CrossRef] [PubMed]

121. Ahmed, J.; Cao, H.; Panteleimonitis, S.; Khan, J.; Parvaiz, A. Robotic vs laparoscopic rectal surgery in high-risk patients. Color. Dis. 2017, 19, 1092-1099. [CrossRef]

122. Al-Mazrou, A.M.; Chiuzan, C.; Kiran, R.P. The robotic approach significantly reduces length of stay after colectomy: A propensity score-matched analysis. Int. J. Color. Dis. 2017, 32, 1415-1421. [CrossRef] [PubMed] 
123. Bertelsen, C.A.; Andreasen, A.H.; Jørgensen, T.; Harling, H.; on behalf of the Danish Colorectal Cancer Group. Anastomotic leakage after curative anterior resection for rectal cancer: Short and long term outcome. Color. Dis. 2009, 12, e76-e81. [CrossRef]

124. Eberl, T.; Jagoditsch, M.; Klingler, A.; Tschmelitsch, J. Risk factors for anastomotic leakage after resection for rectal cancer. Am. J. Surg. 2008, 196, 592-598. [CrossRef] [PubMed]

125. Lipska, M.A.; Bissett, I.P.; Parry, B.R.; Merrie, A.E.H. Anastomotic Leakage after Lower Gastrointestinal Anastomosis: Men Are at a Higher Risk. ANZ J. Surg. 2006, 76, 579-585. [CrossRef] [PubMed]

126. Gu, W.-L.; Wu, S.-W. Meta-analysis of defunctioning stoma in low anterior resection with total mesorectal excision for rectal cancer: Evidence based on thirteen studies. World J. Surg. Oncol. 2015, 13, 9. [CrossRef] [PubMed]

127. Chen, J.; Wang, D.-R.; Yu, H.-F.; Zhao, Z.-K.; Wang, L.-H.; Li, Y.-K. Defunctioning Stoma in Low Anterior Resection for Rectal Cancer: A Meta-Analysis of Five Recent Studies. Hepatogastroenterology 2011, 59, 1828-1831. [CrossRef] [PubMed]

128. Mrak, K.; Uranitsch, S.; Pedross, F.; Heuberger, A.; Klingler, A.; Jagoditsch, M.; Weihs, D.; Eberl, T.; Tschmelitsch, J. Diverting ileostomy versus no diversion after low anterior resection for rectal cancer: A prospective, randomized, multicenter trial. Surgery 2016, 159, 1129-1139. [CrossRef] [PubMed]

129. Chen, J.; Zhang, Y.; Jiang, C.; Yu, H.; Zhang, K.; Zhang, M.; Zhang, G.-Q.; Zhou, S.-J. Temporary ileostomy versus colostomy for colorectal anastomosis: Evidence from 12 studies. Scand. J. Gastroenterol. 2013, 48, 556-562. [CrossRef] [PubMed]

130. Rondelli, F.; Reboldi, P.; Rulli, A.; Barberini, F.; Guerrisi, A.; Izzo, L.; Bolognese, A.; Covarelli, P.; Boselli, C.; Becattini, C.; et al. Loop ileostomy versus loop colostomy for fecal diversion after colorectal or coloanal anastomosis: A meta-analysis. Int. J. Color. Dis. 2009, 24, 479-488. [CrossRef] [PubMed]

131. Gastinger, I.; Marusch, F.; Steinert, R.; Wolff, S.; Koeckerling, F.; Lippert, H. Protective defunctioning stoma in low anterior resection for rectal carcinoma. BJS 2005, 92, 1137-1142. [CrossRef] [PubMed]

132. Hüser, N.; Michalski, C.W.; Erkan, M.; Schuster, T.; Rosenberg, R.; Kleeff, J.; Friess, H. Systematic Review and Meta-Analysis of the Role of Defunctioning Stoma in Low Rectal Cancer Surgery. Ann. Surg. 2008, 248, 52-60. [CrossRef]

133. Åkesson, O.; Syk, I.; Lindmark, G.; Buchwald, P. Morbidity related to defunctioning loop ileostomy in low anterior resection. Int. J. Color. Dis. 2012, 27, 1619-1623. [CrossRef] [PubMed]

134. Floodeen, H.; Hallböök, O.; Hagberg, L.; Matthiessen, P. Costs and resource use following defunctioning stoma in low anterior resection for cancer-A long-term analysis of a randomized multicenter trial. Eur. J. Surg. Oncol. (EJSO) 2017, 43, 330-336. [CrossRef]

135. Tortorelli, A.P.; Alfieri, S.; Sanchez, A.M.; Rosa, F.; Papa, V.; Di Miceli, D.; Bellantone, C.; Doglietto, G.B. Anastomotic leakage after anterior resection for rectal cancer with mesorectal excision: Incidence, risk factors, and management. Am. Surg. 2015, 81, 41-47. [CrossRef] [PubMed]

136. Matthiessen, P.; Hallböök, O.; Rutegård, J.; Simert, G.; Sjödahl, R. Defunctioning Stoma Reduces Symptomatic Anastomotic Leakage After Low Anterior Resection of the Rectum for Cancer: A Randomized Multicenter Trial. Ann. Surg. 2008, 247, 719-720. [CrossRef]

137. Abudeeb, H.; Hammad, A.; Ugwu, A.; Darabnia, J.; Malcomson, L.; Maung, M.; Khan, K.; Mclaughlin, C.; Mukherjee, A. Defunctioning stoma- a prognosticator for leaks in low rectal restorative cancer resection: A retrospective analysis of stoma database. Ann. Med. Surg. 2017, 21, 114-117. [CrossRef] [PubMed]

138. Shiomi, A.; Ito, M.; Maeda, K.; Kinugasa, Y.; Ota, M.; Yamaue, H.; Shiozawa, M.; Horie, H.; Kuriu, Y.; Saito, N. Effects of a Diverting Stoma on Symptomatic Anastomotic Leakage after Low Anterior Resection for Rectal Cancer: A Propensity Score Matching Analysis of 1,014 Consecutive Patients. J. Am. Coll. Surg. 2015, 220, 186-194. [CrossRef] [PubMed]

139. Kapiteijn, E.; Marijnen, C.A.; Nagtegaal, I.D.; Putter, H.; Steup, W.H.; Wiggers, T.; Rutten, H.J.; Pahlman, L.; Glimelius, B.; Van Krieken, J.H.; et al. Preoperative Radiotherapy Combined with Total Mesorectal Excision for Resectable Rectal Cancer. N. Engl. J. Med. 2001, 345, 638-646. [CrossRef] [PubMed]

140. Zhang, H.-Y.; Zhao, C.-L.; Xie, J.; Ye, Y.-W.; Sun, J.-F.; Ding, Z.-H.; Xu, H.-N.; Ding, L. To drain or not to drain in colorectal anastomosis: A meta-analysis. Int. J. Color. Dis. 2016, 31, 951-960. [CrossRef] [PubMed]

141. Rondelli, F.; Bugiantella, W.; Vedovati, M.C.; Balzarotti, R.; Avenia, N.; Mariani, E.; Agnelli, G.; Becattini, C. To drain or not to drain extraperitoneal colorectal anastomosis? A systematic review and meta-analysis. Color. Dis. 2013, 16, O35-O42. [CrossRef] [PubMed]

142. Qu, H.; Liu, Y.; Bi, D.-S. Clinical risk factors for anastomotic leakage after laparoscopic anterior resection for rectal cancer: A systematic review and meta-analysis. Surg. Endosc. 2015, 29, 3608-3617. [CrossRef]

143. Menahem, B.; Vallois, A.; Alves, A.; Lubrano, J. Prophylactic pelvic drainage after rectal resection with extraperitoneal anastomosis: Is it worthwhile? A meta-analysis of randomized controlled trials. Int. J. Color. Dis. 2017, 32, 1531-1538. [CrossRef] [PubMed]

144. Guerra, F.; Giuliani, G.; Coletta, D.; Boni, M.; Rondelli, F.; Bianchi, P.P.; Coratti, A. A Meta-Analysis of Randomized Controlled Trials on the Use of Suction Drains Following Rectal Surgery. Dig. Surg. 2017, 35, 482-490. [CrossRef] [PubMed]

145. Denost, Q.; Rouanet, P.; Faucheron, J.-L.; Panis, Y.; Meunier, B.; Cotte, E.; Meurette, G.; Kirzin, S.; Sabbagh, C.; Loriau, J.; et al. To Drain or Not to Drain Infraperitoneal Anastomosis After Rectal Excision for Cancer. Ann. Surg. 2017, 265, 474-480. [CrossRef]

146. Choi, H.-K.; Law, W.-L.; Ho, J.W.C. Leakage After Resection and Intraperitoneal Anastomosis for Colorectal Malignancy: Analysis of Risk Factors. Dis. Colon Rectum 2006, 49, 1719-1725. [CrossRef] [PubMed]

147. McDermott, F.; Collins, D.; Heeney, A.; Winter, D.C. Minimally invasive and surgical management strategies tailored to the severity of acute diverticulitis. BJS 2013, 101, e90-e99. [CrossRef] [PubMed] 
148. Oberkofler, C.E.; Rickenbacher, A.; Raptis, D.A.; Lehmann, K.; Villiger, P.; Buchli, C.; Grieder, F.; Gelpke, H.; Decurtins, M.; Tempia-Caliera, A.A.; et al. A Multicenter Randomized Clinical Trial of Primary Anastomosis or Hartmann's Procedure for Perforated Left Colonic Diverticulitis With Purulent or Fecal Peritonitis. Ann. Surg. 2012, 256, 819-827. [CrossRef]

149. Buchs, N.; Gervaz, P.; Secic, M.; Bucher, P.; Mugnier-Konrad, B.; Morel, P. Incidence, consequences, and risk factors for anastomotic dehiscence after colorectal surgery: A prospective monocentric study. Int. J. Color. Dis. 2008, 23, 265-270. [CrossRef]

150. Matthiessen, P.; Hallbook, O.; Andersson, M.; Rutegard, J.; Sjodahl, R. Risk factors for anastomotic leakage after anterior resection of the rectum. Color. Dis. 2004, 6, 462-469. [CrossRef] [PubMed]

151. Iancu, C.; Mocan, L.C.; Todea-Iancu, D.; Mocan, T.; Acalovschi, I.; Ionescu, D.; Zaharie, F.V.; Osian, G.; I Puia, C.; Muntean, V. Host-related predictive factors for anastomotic leakage following large bowel resections for colorectal cancer. J. Gastrointest. Liver Dis. 2008, 17, 299-303.

152. Hayden, D.M.; Pinzon, M.C.M.; Francescatti, A.B.; Saclarides, T.J. Patient factors may predict anastomotic complications after rectal cancer surgery. Ann. Med. Surg. 2015, 4, 11-16. [CrossRef]

153. Marinello, F.; Baguena, G.; Lucas, E.; Frasson, M.; Hervas, D.; Flor-Lorente, B.; Esclapez, P.; Espí, A.; García-Granero, E. Anastomotic leakage after colon cancer resection: Does the individual surgeon matter? Color. Dis. 2016, 18, 562-569. [CrossRef] [PubMed]

154. Lai, R.; Lu, Y.; Li, Q.; Guo, J.; Chen, G.; Zeng, W. Risk factors for anastomotic leakage following anterior resection for colorectal cancer: The effect of epidural analgesia on occurrence. Int. J. Color. Dis. 2013, 28, 485-492. [CrossRef] 